dr hab. Krzysztof Dragon, prof. ucz. ${ }^{1}$

prof. dr hab. Tomasz Zieliński ${ }^{1}$

\title{
PROBLEMATYKA HYDROGEOLOGICZNA W CZASOPIŚMIE GEOLOGOS
}

https://doi.org/10.18778/8220-655-5.07

\begin{abstract}
Streszczenie: W artykule zaprezentowano jedno z nielicznych polskich czasopism naukowo-badawczych Geologos dedykowane zagadnieniom geologicznym i hydrogeologicznym. Po krótkim streszczeniu historii czasopisma przedstawiono współcześnie obowiązujące zasady publikowania wraz z procesem recenzyjnym, publikacyjnym, dystrybucji i zasad rozpowszechniania jakie obowiązują w Geologosie. Opisano także profil czasopisma wraz z omówieniem geograficznego rozkładu obiektów badanych i opisywanych w czasopiśmie. Na tym tle przedstawiono rozkład tematyczny artykułów w Geologosie ze szczegółowym omówieniem tematyki hydrogeologicznej w artykułach naukowych publikowanych w okresie ostatnich 5 lat.
\end{abstract}

Słowa kluczowe: hydrogeologia, Geologos, czasopismo naukowe, trendy badawcze.

\section{Wprowadzenie}

Polscy hydrogeolodzy mają jedno polskojęzyczne czasopismo skoncentrowane na tematyce wód podziemnych (Hydrogeologia). Na świecie, owszem, istnieje kilka tytułów czasopism poświęconych zagadnieniom hydrogeologicznym. Wymienić tu należy chociażby Hydrogeology Journal (sztandarowe czasopismo międzynarodowej asocjacji hydrogeologów - IAH), czy Groundwater. Są to najczęściej periodyki „z najwyższej półki”, tj. rangi Journal Citation Reports (JCR czyli tzw. lista filadelfijska). Każdy artykuł tam opublikowany jest dla badacza, szczególnie polskiego, nobilitacją. Jednak na liście filadelfijskiej świat nauki nie kończy się. Najczęściej zajmujemy się bowiem problemami regionalnymi, a nasze publikacje interesują głównie czytelnika krajowego. Wróćmy więc na grunt polskiej nauki i z tej perspektywy prześledźmy profil czasopisma Geologos.

\section{Rys historii i współczesności czasopisma Geologos}

Pierwszy numer czasopisma ukazał się w 1996 roku, w sześć lat po powstaniu Instytutu Geologii Wydziału Nauk Geograficznych i Geologicznych Uniwersytetu im. Adama Mickiewicza w Poznaniu. W końcu ubiegłego wieku autorzy publikowanych prac wywodzili się głównie z macierzystej uczelni czasopisma. Zwykle wychodził wówczas jeden tom na rok. Oprócz prac w języku polskim pojawiały się już również teksty po angielsku. Obok tomów składających się z artykułów, wydawana była też seria Geologos Monographiae, zawierająca obszerne opracowania monograficzne. Przełom nastąpił w 2008 roku, gdy Geologos zmienił swą szatę graficzną i zaczął być wydawany w większym formacie (ryc. 1).

\footnotetext{
${ }^{1}$ Uniwersytet im. Adama Mickiewicza w Poznaniu, Wydział Nauk Geograficznych i Geologicznych, Instytut Geologii, ul. Bogumiła Krygowskiego 10, 61-680 Poznań, geologos@amu.edu.pl, ORCID 0000-0001-57670783, ORCID 0000-0001-9018-0276
} 


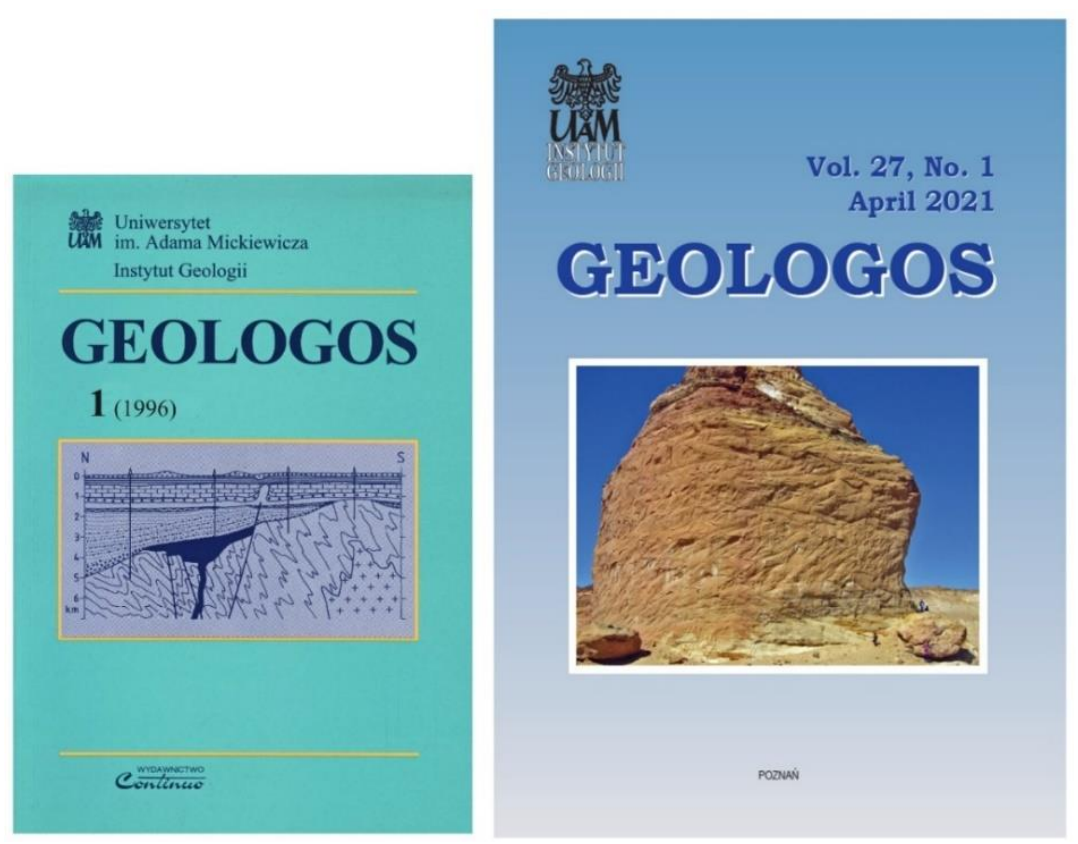

Ryc. 1. Okładka czasopisma Geologos (objaśnienia w tekście)

Źródło: materiały własne

Po roku odstąpiono od zasady publikowania prac w języku polskim, koncentrując się na artykułach angielskojęzycznych. Obecnie, co roku ukazują się trzy numery czasopisma. Każdy numer oprócz oryginalnych studiów (research papers) zawiera recenzje książek geologicznych ukazujących się aktualnie na rynku. Publikowane są również artykuły informacyjne - sprawozdania z konferencji, a także krótsze artykuły będące dyskusjami lub polemikami naukowymi (dział Miscellaneous). Redakcja otwarta jest również na publikacje numerów specjalnych (Special Issue), co najczęściej odbywa się jako pokłosie konferencji.

\section{Proces recenzyjny artykułów}

Redakcja przyjęła zasadę, że każdy manuskrypt poddawany jest dwóm recenzjom. Staramy się, aby jeden recenzent zawsze był krajowy, natomiast drugi zagraniczny. Recenzenci są anonimowi dla autorów prac. Pod koniec każdego roku publikujemy wykaz recenzentów w ramach zbiorowego podziękowania. Redakcja dba o to, by recenzje były fachowe i sprawiedliwe, a z drugiej strony - przyjazne autorom manuskryptów.

\section{Proces publikacyjny}

Zaaprobowane do druku manuskrypty poddawane są edycji redaktorskiej. Niedociągnięcia lingwistyczne poprawiane są przez redaktora językowego - doświadczonego zagranicznego geologa. Czasopismo Geologos gwarantuje tę usługę bezpłatnie. Dbamy również o wysoki poziom szaty graficznej publikowanych artykułów poprzez odpowiednie programy poprawiające jakość figur i fotografii. Wciąż trzymamy się zasady dostarczania autorom drukowanych wersji czasopisma wraz z nadbitkami. 


\section{Rozpowszechnianie artykułów}

Zawartość czasopisma Geologos jest powszechnie dostępna w wersji elektronicznej (status open access). Widoczność publikacji na ,rynku nauki” to niezwykle istotny problem będący w gestii naszej redakcji. Wszystkie publikowane artykuły znajdują się w bazie Web of Science oraz Scopus. Te dwie bazy są powszechnie uznawane przez naukowców na całym świecie jako podstawowe narzędzia bibliograficzne. Kolejne wydania czasopisma są oczywiście dostępne na stronie internetowej (www.geologos.com.pl), a ponadto publikowane w pełnych wersjach na platformie renomowanego wydawcy publikacji naukowych De Gruyter - portal Sciendo (sciendo.com/pl). Drukowane wersje czasopisma rozsyłane są do bibliotek wszystkich ośrodków naukowych w Polsce oraz najważniejszych ośrodków akademickich Europy. Redakcja dba również o bardziej indywidualną dystrybucję treści czasopisma. Informacja o publikacji każdego artykułu Geologos rozsyłana jest do naukowców w kraju i za granicą, którzy opublikowali prace na ten sam lub podobny temat.

\section{Profil czasopisma w okresie ostatnich pięciu lat}

Każdego roku w czasopiśmie Geologos publikowanych jest od 15. do 25. artykułów naukowych. Co ciekawe, autorzy zagraniczni najczęściej przeważają nad krajowymi (ryc. 2). Wynika to niewątpliwie $\mathrm{z}$ tendencji do publikowania wyników badań w czasopismach spoza granic własnego kraju. Redakcja Geologos pragnie odwrócić tę tendencję, gdyż uważamy, że na terenie Polski wciąż istnieje wiele nierozwiązanych problemów geologicznych, a ponadto - chcemy, by Geologos był czasopismem w pierwszej kolejności poczytnym w Polsce.

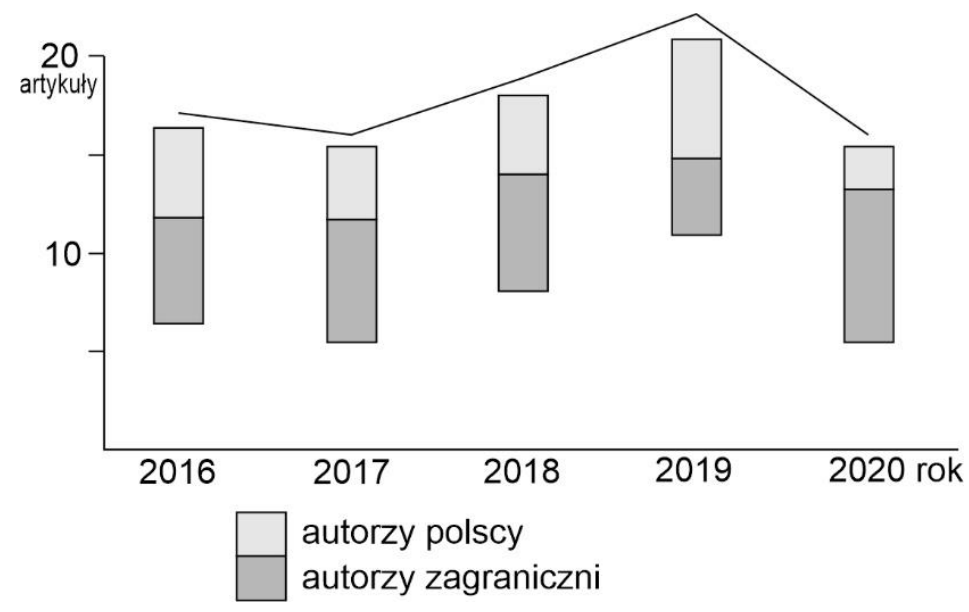

Ryc. 2. Autorstwo publikacji w czasopiśmie

Źródło: opracowanie własne

Geograficzny rozkład obiektów badanych i opisywanych w czasopiśmie z obszaru Polski (ryc. 3) nie wykazuje jakiejkolwiek regionalizacji publikowanych badań. Pod tym względem Geologos jest ogólnokrajowy. 


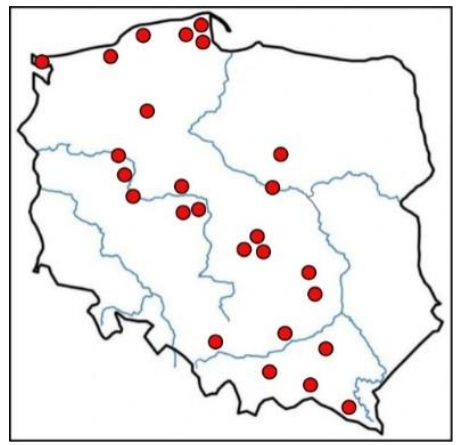

Ryc. 3. Geograficzny rozkład obiektów badanych i opisywanych w czasopiśmie z obszaru Polski Źródło: opracowanie własne

Jeżeli popatrzymy na mapę opracowań zagranicznych (ryc. 4), to widać, że oprócz Europy publikowane badania obejmują sporą część Azji, a nawet Afrykę. Znacząca liczba studiów poświęcona jest rejonom o stosunkowo słabym rozpoznaniu geologicznym. Takie odkrywane terra incognito to Nigeria, wielkie przestrzenie Rosji, Chin, Indii i Iranu, a nawet Hiszpania. Liczne artykuły z Chin i Indii to również odwzorowanie trendu widocznego w całej światowej bibliografii geologicznej - istnej inwazji publikacji z tych rejonów świata.

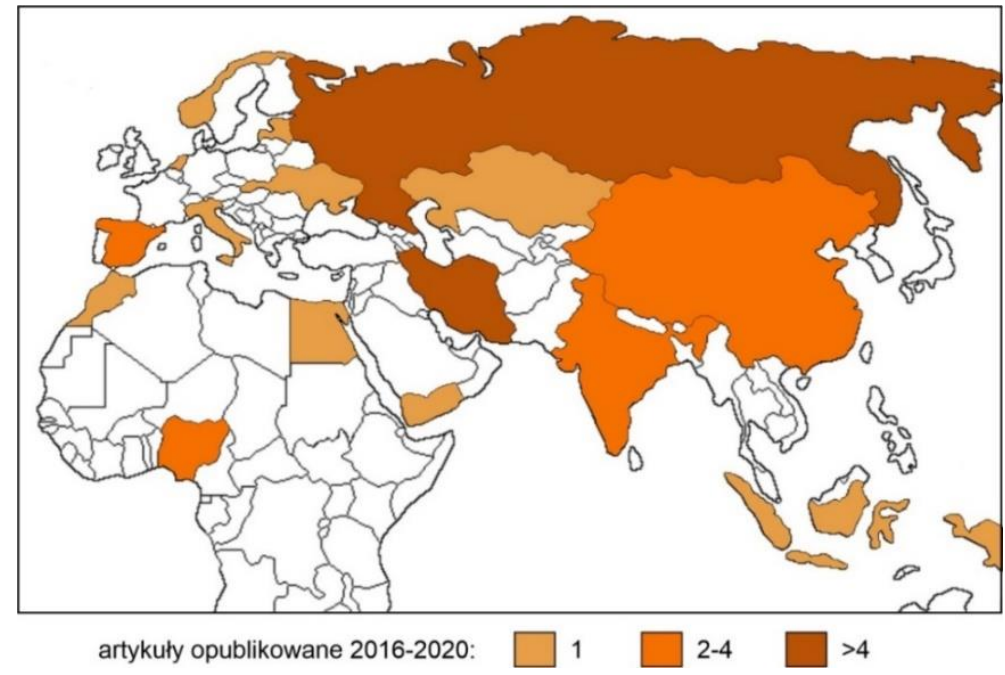

Ryc. 4. Przestrzenny rozkład liczby autorów zagranicznych

Źródło: opracowanie własne

A jak wygląda rozkład tematyczny artykułów w Geologos? Wykres (ryc. 5) jednoznacznie pokazuje rozdział na dwie zasadnicze grupy. Najpopularniejsze działy tematyczne to: sedymentologia, hydrogeologia, geochemia z petrologią i mineralogią, paleontologia. Wszelkie inne działy (włącznie ze stratygrafią, tektoniką i petrofizyką) reprezentowane są w wyraźnie mniejszym stopniu.

O zainteresowaniu hydrogeologów czasopismem Geologos niech świadczą chociażby wybrane statystyki z ostatnich 5. lat publikacji czasopisma (lata 2016-2021). Ukazało się w tym 
czasie 16 numerów czasopisma, w których znalazło się 21 artykułów o tematyce hydrogeologicznej. Spośród wymienionych 16 . numerów czasopisma, 2 poświęcone były wyłącznie problematyce wód podziemnych (special issue). W analizowanych latach w czasopiśmie zamieszczono też kilka recenzji książek o tematyce „wodnej”.

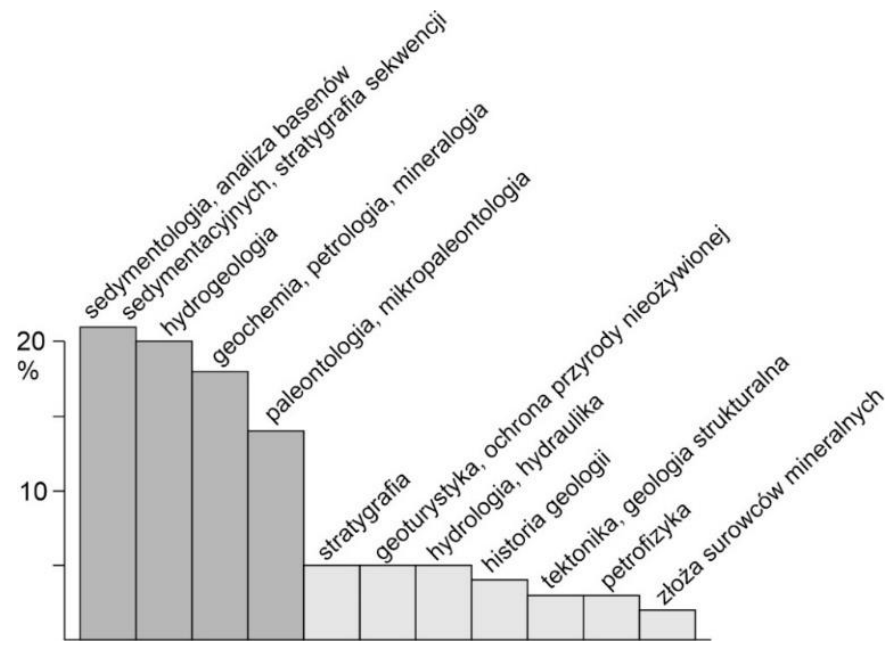

Ryc. 5. Tematyka artykułów publikowanych w czasopiśmie Źródło: opracowanie własne

Tematyka artykułów w zakresie hydrogeologii jest bardzo zróżnicowana i dotyczy praktycznie wszystkich aspektów hydrogeologii. Wiele artykułów poświęconych było zagadnieniom infiltracji brzegowej i to zarówno w aspekcie kolmatacji dna koryta rzecznego w warunkach eksploatacji ujęć (Kaczmarek 2017, Przybyłek i in. 2017) jak i w aspekcie zmienności chemizmu wód w warunkach infiltracji brzegowej (Górski i in. 2021), czy też w aspekcie naturalnego uzdatniania wód w warunkach zasilania infiltracyjnego różnych typów infiltracyjnych ujęć wód (Górski i in. 2018). Duża liczba artykułów poświęcona była tematyce modelowania matematycznego przepływu wód podziemnych. Artykuły te dotyczyły przede wszystkim analizy warunków krążenia wód (Dendys i in. 2018; Hoc i in. 2018, 2019; Kordalski i Sadurski 2018; Zdechlik i Kałuża 2019), modelowania transportu zanieczyszczeń (Sieczka i in. 2018, Pietrzak i in. 2019), czy też wykorzystania metod modelowania matematycznego do określania dopływu wód do kopalń cynku i ołowiu (Juśko i in. 2018) oraz modelowania warunków zasilania płytkich wód podziemnych (Graf i Przybyłek 2018). Publikowane były również artykuły dotyczące oceny warunków krążenia wód podziemnych (Jamorska i in. 2019). W ostatnim czasie z coraz większą popularnością publikowane są artykuły dotyczące nowo pojawiających się zanieczyszczeń w wodach podziemnych, np. farmaceutyków (Kuczyńska 2019, Okońska 2019) oraz wykorzystania nowych metod badań hydrogeologicznych, w tym nowych metod oceny niepewności wyników analiz składu chemicznego (Wątor i in. 2019), czy też wykorzystania metod teledetekcji do oceny ryzyka wystąpienia i zasięgu powodzi (Solovey 2019). Liczne są też artykuły dotyczące wykorzystania metod izotopowych w hydrogeologii (Duliński i in. 2019, Kotoski i Satora 2016, Leśniak i Wilamowski 2019). 
Problematyka hydrogeologiczna w czasopiśmie Geologos

\section{Bibliografia}

Dendys M., Szczepański A., Tomaszewska B., 2018, Groundwater circulation in the Miechów Trough and the central part of the Carpathian Foredeep (Poland): a hydrogeological conceptual model, Geologos, 24(3): 177-187.

Duliński M., Gorczyca Z., Marzec M., Czub R., Brudnik K., 2019, Radiocarbon dating of groundwater from a PZ-2 piezometer located in the foreground of Wieliczka Salt Mine, Poland, Geologos, 25(3): 187-192.

Górski J., Dragon K., Kruć R., 2018, A comparison of the efficiency of riverbank filtration treatments in different types of wells, Geologos, 24(3): 245-251.

Górski J., Dragon K., Kruć-Fijałkowska R., Matusiak M., 2021, Assessment of river water infiltration conditions based on both chloride mass-balance and hydrogeological setting: the Krajkowo riverbank filtration site (Poland), Geologos, 27(1): 35-41.

Graf R., Przybyłek J., 2018, Application of the WetSpass simulation model for determining conditions governing the recharge of shallow groundwater in the Poznan Upland, Poland, Geologos, 24(3): 189-205.

Hoc R., Sadurski A., Wiśniowski Z., 2018, A groundwater flow model for the Wolin Island area, including glaciotectonic deformation, Geologos, (24)3: 207-216.

Hoc R., Sadurski A., Wiśniowski Z., 2019, Possibilities of safe yield increase in the Wydrzany well field (Uznam Island, Poland) by surface water from a drainage system, Geologos, 25(3): 263-270.

Jamorska I., Kubiak-Wójcicka K., Krawiec A., 2019, Dynamics of the status of groundwater in the Polish Lowland: the River Gwda catchment example, Geologos, 25(3): 193-204.

Juśko K., Motyka J., d'Obyrn K., Adamczyk Z., 2018, Construction of a numerical groundwater flow model in areas of intense mine drainage, as exemplified by the Olkusz Zinc and Lead Ore Mining Area in southwest Poland, Geologos, 24(3): 237-244.

Kaczmarek P., 2017, Hydraulic conductivity changes in river valley sediments caused by river bank filtration - an analysis of specific well capacity, Geologos, 23(2): 123-129.

Kordalski Z., Sadurski A., 2018, Groundwater flow modelling of main groundwater reservoirs in the Gdansk region, Poland, Geologos, 24(3): 217-224.

Kotowski T., Satora S., 2016, Isotope characterisation of deep aquifers in the Gwda catchment, northern Poland, Geologos, 22(2): 137-147.

Kuczyńska A., 2019, Presence of pharmaceutical compounds in groundwater with respect to land use in the vicinity of sampling sites, Geologos, 25(3): 231-240.

Leśniak P., Wilamowski A., 2019, The $\delta 18 O$ and $\delta$ Disoscapes of recent groundwater in Poland, Geologos, 25(3): 205-211.

Okońska M., Marciniak M., Zembrzuska J., Kaczmarek M., 2019, Laboratory investigations of diclofenac migration in saturated porous media - a case study, Geologos, 25(3): 213223.

Pietrzak D., Kania J., Kmiecik E., Wątor K., 2019, Identification of transport parameters of chlorides in different soils on the basis of column studies, Geologos, 25(3): 225-229. 
Przybyłek J., Dragon K., Kaczmarek P., 2017, Hydrogeological investigations of river bed clogging at a river bank filtration site along the River Warta, Poland, Geologos, 23(3): 201-214.

Sieczka A., Bujakowski F., Koda E., 2018, Modelling groundwater flow and nitrate transport: a case study of an area used for precision agriculture in the middle part of the Vistula River valley, Poland, Geologos, 24(3): 225-235.

Solovey T., 2019, An analysis of flooding coverage using remote sensing within the context of risk assessment, Geologos, 25(3): 241-248

Wątor K., Kmiecik E., Postawa A., Rusiniak P., 2019, A probabilistic approach to assessment of the quality of drinking water, Geologos, 25(3): 249-254.

Zdechlik R., Kałuża A., 2019, The FEM model of groundwater circulation in the vicinity of the Świniarsko intake, near Nowy Sacz (Poland), Geologos, 25(3): 255-262. 